\title{
Genetic characterization and phylogenetic study of Indonesian indigenous catfish based on mitochondrial cytochrome B gene
}

\author{
Dorothea Vera Megarani ${ }^{1}$, Herjuno Ari Nugroho' ${ }^{2}$, Zahrah Prawita Andarini ${ }^{3}$, Yura Dwi Risa B. R. Surbakti ${ }^{3}$ and
} Rini Widayanti ${ }^{4}$

1. Department of Clinical Pathology, Faculty of Veterinary Medicine, Universitas Gadjah Mada, Yogyakarta, Indonesia;

2. Research Center for Biology, Indonesian Institute of Sciences (LIPI), Cibinong, West Java, Indonesia; 3. Veterinary

Medicine Undergraduate Program, Faculty of Veterinary Medicine, Universitas Gadjah Mada, Yogyakarta, Indonesia;

4. Department of Biochemistry and Molecular Biology, Faculty of Veterinary Medicine, Universitas Gadjah Mada, Yogyakarta, Indonesia.

Corresponding author: Rini Widayanti, e-mail: rini_widayanti@ugm.ac.id

Co-authors: DVM: dorotheamegarani@ugm.ac.id, HAN: herjunoari@gmail.com, ZPA: zahrapova96@gmail.com, YDRBRS: yura.dwi.r@mail.ugm.ac.id

Received: 09-09-2019, Accepted: 09-12-2019, Published online: 13-01-2020

doi: www.doi.org/10.14202/vetworld.2020.96-103 How to cite this article: Megarani DV, Nugroho HA, Andarini ZP, Surbakti YDRBR, Widayanti R (2020) Genetic characterization and phylogenetic study of Indonesian indigenous catfish based on mitochondrial cytochrome B gene, Veterinary World, 13(1): 96-103.

\begin{abstract}
Aim: This study aimed to determine the genetic characterization and phylogenetic structure of Indonesian indigenous catfish using cytochrome B (Cyt B) sequences.

Materials and Methods: The genomes of 26 catfishes caught from nine rivers from nine different geographical locations around Indonesia were analyzed. The tissue isolation method was used to isolate the total genome of the fishes. Furthermore, polymerase chain reaction was done to amplify the mtDNA Cyt B using the CytBF and CytBR primers. Following sequencing, the analysis of genetic variation and the phylogenetic relationship was performed using MEGA version X software.

Results: Cyt B gene sequencing attained a total of 1139 nucleotides encrypting 379 amino acids for all samples. The ClustalW alignment program using MEGA X software revealed 395 substituted nucleotides, which then translated into 63 amino acid variation sites among all 26 samples. No amino acids in catfish BB were different compared to catfish PM, MP, and KR2,3. Catfish MS had one modified amino acid; KR1 and KS had two different amino acids; BF had 38 different amino acids; EM had 31 different amino acids; and BSBJ had 26 different amino acids compared to catfish BB. The most significant alteration of amino acids was between catfish EM and BF (49 amino acids).

Conclusion: Indonesian catfish were divided into five clades based on the Cyt B gene. Samples KR and MP (Sumatra); MS and BB (Kalimantan); and PM (Java) were clustered with Hemibagrus nemurus and Hemibagrus wyckioides (Bagridae family). Samples from Kalimantan (KS) and one sample of KR (KR1) from Sumatra were clustered with Sperata seenghala and Hemibagrus spilopterus (Bagridae family). Samples from Java (BSBJ) were clustered with Pseudolais pleurotaenia (Pangasiidae family). Samples EM (Java) were together with Mystus cavasius (Bagridae family). Samples from West Papua were clustered with Potamosilurus latirostris (Ariidae family).
\end{abstract}

Keywords: cytochrome B, Indonesian indigenous catfish, mitochondrial DNA, phylogenetic study, Siluriformes.

\section{Introduction}

Indonesia is a country that features exceptional biodiversity, including a wide variety of fish species. There is an exceedingly large number of indigenous fishes that can be found in Indonesia, one of which is catfish (Siluriformes). This group of fish consists of 106 species, which are grouped into 35 genera and 12 families, including Bagridae, Pangasiidae, Siluridae, Schilbeidae, Akysidae, Parakysidae, Sisoridae, Ariidae, Plotosidae, Loricariidae, Clariidae, and Chacidae. These catfishes live in streams of Sumatra, Java, Kalimantan, Sulawesi, and Papua Island [1].

Copyright: Megarani, et al. Open Access. This article is distributed under the terms of the Creative Commons Attribution 4.0 International License (http://creativecommons.org/licenses/ by/4.0/), which permits unrestricted use, distribution, and reproduction in any medium, provided you give appropriate credit to the original author(s) and the source, provide a link to the Creative Commons license, and indicate if changes were made. The Creative Commons Public Domain Dedication waiver (http:// creativecommons.org/publicdomain/zero/1.0/) applies to the data made available in this article, unless otherwise stated.
Due to their identical appearance and close relations, there are difficulties in differentiating their species. Furthermore, local people tend to use the same term for anyone of the catfishes which have acquired the recognition of Indonesian for being a good source of protein and other nutritional values, which is Baung catfish [1,2]. A previous study classified this particular catfish into Hemibagrus nemurus, which is in the Bagridae family [3]. Nonetheless, another study of Baung catfish originally from East Java Indonesia allocated this catfish into the Pangasiidae family based on the cytochrome $\mathrm{C}$ oxidase subunit 3 (COX-III) gene [4]. Therefore, further studies of the genetic markers of these indigenous catfishes, known as Baung catfish to local people in Indonesia, are needed to identify the catfish species and preserve their genetic resources. Such a genetic study is one of the first steps in the conservation strategy of Indonesian indigenous catfishes, which are presently starting to decrease in the wild [5]. The rapid fishing 
of native catfish without proper preservation and lack of protection from water contamination have caused a significant threat to their population.

Mitochondrial DNA (mtDNA) is widely used as a useful target for species identification and genetic diversity studies due to several reasons, including the number of mtDNA is higher than the nuclear DNA, and it is only passed down by the mother [6]. Cytochrome $\mathrm{B}$ (Cyt B) gene is one of the genes which is coded by mtDNA and plays a significant role in the transfer of electrons in the respiratory tract. Molecular analyses of the animal species using the Cyt B gene have been done in preceding studies, including Haliaeetus leucogaster [7,8], Macrocephalon maleo [9], Capra hircus [10], and Scomberomorus sp. [11]. This gene is widely used to examine the relationship of the same genus or family and the phylogenetic studies of cuscus from Maluku (Spilocuscus maculatus, Spilocuscus rufoniger, Phalanger orientalis, and Phalanger vestitus) [12]. The encoding gene is used as a genetic marker because the codons are based on position and have more conserve and diverse regions [13]. The Cyt $\mathrm{B}$ gene has a moderate evolutionary level and a clear evolution pattern, making it suitable for phylogenetic evolution studies at intraspecific and interspecific levels $[14,15]$. Another mitochondrial gene that can be used for the barcoding is cytochrome $\mathrm{C}$ oxidase subunit 1 (COX-I) gene. In contrast with $\mathrm{Cyt} \mathrm{B}$, which is commonly used for determining the phylogenetic relationships within families and genera, the COX-I gene is suitable for identifying individuals belonging to the same species and distinguishing between individuals from different species $[16,17]$. The mutation rate of the $\mathrm{CO} 1$ gene sequence is slow enough so that the sequence is identical in the same species, yet it is fast enough so that it would be different between species [16].

This study aimed to study the Cyt B gene of the indigenous catfish from different parts of Indonesia known as Baung catfish for local people and to determine the diversity as well as the phylogenetic relationship among them using Cyt B as the genetic marker and comparing them with the available sequence records from the GenBank. Moreover, the genetic variability of catfish in Cyt B region was measured to get the DNA barcoding of catfish among different regions from the mtDNA sequences.

\section{Materials and Methods}

\section{Ethical approval}

This study was approved by the Animal Ethics Committee for using Animal and Scientific Procedures in the Faculty of Veterinary Medicine, Universitas Gadjah Mada, Indonesia.

\section{Sample collections}

A total of 26 catfish from different parts of Indonesia known as Baung catfish for local people were collected from nine different streams or rivers from eight provinces on four islands [4]. The origin and the total number of the samples collected are presented in Table-1. To prevent any bias in the genetic analysis, each of the samples was taken individually from its habitat, and they were identified based on their morphological features. Tissue samples were first preserved in the RNAlatter buffer (Qiagen) and then used for the total DNA isolation.

\section{DNA extraction and amplification}

gSYNC $^{\mathrm{TM}}$ DNA Mini Extraction Kit (Geneaid Biotech Ltd., Taipei, Taiwan) was used for the total DNA isolation from the tissue samples according to the kit's instruction. Extracted total DNA was stored at $-20^{\circ} \mathrm{C}$ until further examination.

\section{Primer design}

Amplification of the target DNA fragments was done by polymerase chain reaction (PCR) using the pair primer of Cyt B $1242 \mathrm{bp}$, which was designed with Primer3 output program (http://www-genome.wi.mit. edu/cgi.bin/primr3.cgi/results_from-primer3) created on the mitochondrial genetic sequence data of H. nemurus (Access number KJ573466.1) and Mystus vittatus (KX177968.1). The pair primer sequence utilized for the Cyt B gene amplification from fish samples was Baung_CytBF5' CCGCTCTGTCACTTTCTTTT 3' andBaung_CytBR-5' GCTCATTTGTGTCCTCCTTT $3^{\prime}$ with the melting temperature of $53.1^{\circ} \mathrm{C}$ and $53^{\circ} \mathrm{C}$, respectively.

\section{Sequencing and phylogenetic analysis}

The sequencing of the purified PCR products was done precisely by $1^{\text {st }}$ Base Sequencing INT (Singapore) and then continued with the analysis of the sequences using the MEGA program version $X$ [18]. DNA forward and reverse sequences of Cyt B gene were aligned with ClustalW. Subsequently, the sequences were first edited, followed by the

Table-1: Samples used in this study.

\begin{tabular}{llcl}
\hline River & Province & Number of samples & Sample codes \\
\hline Elo & Magelang, Central Java & 2 & EM1, EM2 [4] \\
Progo & Magelang, Central Java & 3 & PM1, PM2, PM3 [4] \\
Kampar & Pekanbaru, Riau, Sumatra & 3 & KR1, KR2, KR3 [4] \\
Musi & Palembang, South Sumatra & 3 & MP1, MP2, MP3 [4] \\
Mahakam & Samarinda, East Kalimantan & 3 & MS1, MS2, MS3 [4] \\
Kapuas & Sintang, West Kalimantan & 2 & KS1, KS2 [4] \\
Bengawan Solo & Bojonegoro, East Java & 3 & BSB]1, BSB]2, BSB]3 [4] \\
Barito & Banjarmasin, South Kalimantan & 3 & BB1, BB2, BB3 \\
Bomberay & Fakfak, West Papua & 4 & BF1, BF2, BF3, BF4 \\
\hline
\end{tabular}


multiple alignments with the sequence data related to $H$. nemurus and other catfishes around the world recorded in GenBank. Since the Cyt B gene data were not fully presented in the GenBank, the Cyt B target sequence which was 1091 nucleotides in length was then analyzed to determine the genetic relationship of the species using the Kimura 2-parameter method, with 1000 replicates of the bootstrap method. In addition, the phylogenetic analysis based on the Cyt B sequence was performed using neighbor-joining (NJ). The phylogenetic tree of the samples and the other catfish sequences from the GenBank was assembled based on the Cyt B sequences to depict the relationships between the species and the clusters between the individuals.

\section{Results}

Variation of nucleotides and amino acids sequences

Among the total of 1139 nucleotides Cyt B sequences, which encoded 379 amino acids in 26 samples, there were 395 nucleotides which were substituted. The 395 substituted nucleotides were then translated into 63 amino acid variation sites (Figures-1 and 2). The substitutions of nucleotides resulted in the variation of nucleotides or amino acids [19]. Based on the 63 amino acid variations, there were no amino acids in catfish BB1,2,3 which were different compared to amino acids in catfish PM1,2,3; MP1,2,3; and KR2,3. Nevertheless, catfish MS1,2,3 had one modified amino acid; KR1 and KS1,2 had two different amino acids; BF1,2,3,4 had 38 different amino acids; EM1,2 had 31 different amino acids; and BSBJ1,2,3 had 26 different amino acids compared to catfish BB1,2,3. Further analysis disclosed that the most significant alteration of amino acids was between catfish EM1,2 and catfish BF1,2,3,4, which was 49 amino acids. The amino acid variation of all samples based on Cyt B sequence is presented in Table-2.

\section{Phylogenetic relationships between Indonesian catfish and other catfish species}

The examination of the phylogenetic relationship of the Indonesian catfish samples and other related catfish species was done starting from the nucleotides site $34^{\text {th }}-1124^{\text {th }}$ due to the limited data recorded in GenBank. The taxon identification phenogram of the samples was analyzed by constructing the phylogenetic tree using the NJ method. Figure-3 shows the phylogenetic tree of Indonesian catfish based on the Cyt B nucleotides sequence. Figure-3 shows that the Indonesian catfish were separated into five monophyletic groups or clades, in conjunction with the other catfish species around the world. First, Indonesian catfish samples BF1,2,3,4 were clustered with Potamosilurus latirostris (FJ626223.1). Furthermore, the samples BSBJ1,2,3 were in the same group with Pseudolais pleurotaenia (HM236398.1), while samples EM1,2 were together with Mystus cavasius (KU870465.1). Samples KS 1,2 and KR1 were together with Sperata seenghala and Hemibagrus spilopterus. Finally, samples KR2,3; MS1,2,3; BB1,2,3; MP1,2,3; and PM1,2,3 were in the same cluster with H. nemurus (KJ573466.1) and Hemibagrus wyckioides (KJ624624.1).

The analysis of the phylogenetic tree of Indonesian catfish based on the Cyt B amino acid sequence is shown in Figure-4. Based on the Cyt B amino acid sequence, the Indonesian catfish samples were divided into five different monophyletic groups. Samples BF 1,2,3,4 were together with $P$. latirostris (FJ626223.1), whereas samples BSBJ1,2,3 were in the same clade with P. pleurotaenia (HM236398.1). In addition, samples EM1,2 were grouped with $M$. cavasius (KU870465.1). The fourth group was formed by samples KS1,2 and KR1, which was in the same clade with S. seenghala (AB907556.1) and H. spilopterus (JQ343983.1). Finally, the rest of the samples MS1,2,3; BB1,2,3; PM1,2,3; MP1,2,3; and KR2,3 were in the same group with H. nemurus (KJ573466.1) and H. wyckioides (KJ624624.1).

\section{Discussion}

\section{Genetic variation of Indonesian catfish based on Cyt B sequence}

Catfish (Siluriformes) are frequently found in Asia and Africa throughout fresh-and brackish-water, consisting of more than 200 species in 17 genera and are one of the significant fish orders documented at present [20]. Species catfish from Indonesia which

\begin{tabular}{|c|c|c|c|c|c|c|c|c|c|c|c|c|c|c|c|c|c|c|c|c|c|c|c|c|c|c|c|c|c|c|c|c|c|}
\hline \multirow[t]{2}{*}{ Catfish } & \multicolumn{30}{|c|}{ Amino Acid Sequence } & \multirow[b]{2}{*}{2} & \multirow[b]{2}{*}{2} & \multirow[b]{2}{*}{2} \\
\hline & & & & & & & & & & & & & & & & & 1 & 1 & 1 & 1 & 1 & 1 & 1 & 1 & 1 & 2 & 2 & 2 & 2 & 2 & & & \\
\hline & & & & & 1 & 1 & 1 & 2 & 2 & 4 & 4 & 4 & 5 & 6 & 7 & 9 & 1 & 5 & 5 & 5 & 8 & 8 & 9 & 9 & 9 & 0 & 1 & 1 & 1 & 1 & 1 & 2 & 3 \\
\hline & 2 & 3 & 6 & 9 & 0 & 3 & 5 & 8 & 9 & 1 & 2 & 5 & 8 & 6 & 7 & 3 & 9 & 5 & 7 & 8 & 7 & 8 & 1 & 3 & 4 & 8 & 1 & 3 & 4 & 7 & 8 & 8 & 2 \\
\hline $\mathrm{BB1}, 2,3$ & V & I & $T$ & L & $\mathbf{F}$ & V & D & A & $W$ & $M$ & $M$ & L & 1 & A & 1 & 1 & L & V & D & $M$ & A & 1 & A & $\mathbf{L}$ & $M$ & $\mathbf{L}$ & $\mathbf{N}$ & D & A & 1 & $T$ & V & I \\
\hline PM1,2,3 &. & . & . & . & . & . & . & . & . & . & . & . & . &. & . & . & . & . & . & . & . & . & . & . & . &. & . & . & . & . & . & . & . \\
\hline MP1,2,3 & . & . & . & . & . & . & . & . & . & . & . & . & . & . & . & . & . & . & . & . & . & . & . & . & . & . & . & . & . & . & . & . & . \\
\hline KR1 & . & . & . & . & . & . & . & . & . & . & . & . & V & . & . & . & . & . & . & . & . & . & . & . & . & . & . &. & . &. & . & . & . \\
\hline KR2,3 & . & . & . & . & . & . & . & . & . & . & . & . &. & . & . & . & . & . & . & . & . & . & . & . & . & . & . & . & . & . & . & . & . \\
\hline KS1,2 & . & . & . & . & . & . &. & . &. & . & . & . & V & . & . & . & . & . & . & . & . & . & . & . & . & . & . & . & . & . & . & . & . \\
\hline MS1,2,3 & . & . & . & . & . &. & . & . & . & . &. & . & . & . & . & . & . & . &. & . & . & . & . & . & . &. & . & . & $T$ & . & . & . & . \\
\hline BF1,2,3,4 & I & $T$ & . & 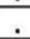 & L & A & $\mathbf{N}$ & . & 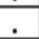 & A & V & $M$ & . & . & . & . & . & $M$ & $\mathbf{N}$ & A & . & . & . & . & L & I & . &. &. & . & $P$ & 1 & . \\
\hline EM1,2 & $T$ & $\mathbf{Y}$ & S & $M$ & L & . & . & $\mathbf{S}$ & $M$ & A & A & . & . & . & V & L & $F$ & $M$ & . & A & . & . & $\mathbf{F}$ &. & I & . & $T$ & $\mathbf{N}$ & $T$ & V & . & . & . \\
\hline BSBJ1,2,3 & . & . & . & . & . & . & . & . & . & . & V & . & . & V & $T$ & . & . & . & . & . & V & V & . & V & L & 1 & . & . & . & . & $\mathrm{S}$ & $M$ & $M$ \\
\hline
\end{tabular}

Figure-1: Polymorphic amino acid sites of Catfish from site 2 to 232. Identification with the first sequences is denoted by a dot. 


\begin{tabular}{|c|c|c|c|c|c|c|c|c|c|c|c|c|c|c|c|c|c|c|c|c|c|c|c|c|c|c|c|c|c|c|}
\hline Catfish & \multicolumn{30}{|c|}{ Amino Acid Sequence } \\
\hline & 2 & 2 & 2 & 2 & 2 & 2 & 3 & 3 & 3 & 3 & 3 & 3 & 3 & 3 & 3 & 3 & 3 & 3 & 3 & 3 & 3 & 3 & 3 & 3 & 3 & 3 & 3 & 3 & 3 & 3 \\
\hline & 3 & 3 & 3 & 3 & 4 & 9 & 0 & 0 & 0 & 0 & 1 & 1 & 2 & 2 & 2 & 2 & 3 & 4 & 4 & 5 & 5 & 5 & 6 & 6 & 6 & 6 & 6 & 7 & 7 & 7 \\
\hline & 3 & 5 & 6 & 9 & 0 & 4 & 1 & 2 & 5 & 8 & 6 & 9 & 0 & 2 & 3 & 6 & 2 & 4 & 7 & 2 & 5 & 9 & 3 & 4 & 5 & 8 & 9 & 0 & 5 & 8 \\
\hline BB1,2,3 & $\mathbf{L}$ & $\mathrm{I}$ & $T$ & A & $\mathbf{S}$ & $\mathbf{L}$ & $M$ & V & $\mathbf{L}$ & $T$ & $\mathbf{F}$ & $\mathbf{L}$ & A & $\mathbf{L}$ & $M$ & $T$ & A & $\mathrm{H}$ & V & $\mathrm{I}$ & $\mathbf{V}$ & A & $\mathbf{F}$ & $L$ & $\mathbf{N}$ & $M$ & $\mathbf{G}$ & $L$ & $\mathbf{L}$ & $\mathbf{F}$ \\
\hline PM1,2,3 & . & . & . & . & . & . & . & . & . & . & 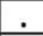 & . & . & . & . & . &. & . & . & . & . &. & . & . & . & $\cdot$ & . & . & . & \\
\hline MP1,2,3 & . & . & . & 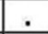 & . & . & $\cdot$ & . & . & . & . & $\cdot$ & $\dot{.}$ & . & . & $\dot{0}$ & . & . & . & . & . & & . & . & . & . & . & . & . & . \\
\hline KR1 & • & . & 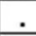 & . & . & 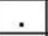 & . & . & $\cdot$ & . & . & . & . & $\cdot$ & . & . & . & . & . & . & . & M & . & . & . & . & . & . & & . \\
\hline KR2,3 & $\cdot$ & . & 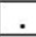 & . & . & . & . & . & . & - & $\cdot$ & . & & . & . & . & • & . & . & . & . & & . & . & . & . & . & . & . & . \\
\hline KS1,2 & . & - & . & . & . & . & . & 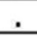 & - & . & . & . & . & . & . & . &. & . & . & . & . & M & . & . & . & . & . & $\dot{.}$ & . & \\
\hline MS1,2,3 & & & & & & & & & & & & & & & & & & & & & & & & & & & & & & \\
\hline BF1,2,3,4 & I & $\mathbf{L}$ & S & $T$ & $\mathbf{F}$ & V & 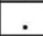 & & M & 1 & 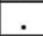 & & $\mathbf{S}$ & & $\mathbf{L}$ & V & $\mathbf{L}$ & D & I & . & I & $\mathbf{S}$ & V & . & s & A & $\mathbf{s}$ & W & $\mathbf{S}$ & $\mathbf{L}$ \\
\hline EM1,2 & & A & . & V & . & . & $\mathbf{L}$ & I & . & . & $\mathbf{Y}$ & 1 & & $F$ & . & 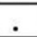 & & . & I & 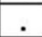 & . & S & I & 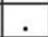 & . & $T$ & . & & . & \\
\hline BSBJ1,2,3 & $\mathbf{F}$ & $\mathbf{L}$ & . & . & . & . & . & L & . & . & . & & $\mathbf{S}$ & . & $L$ & $I$ & $F$ & . & I & V & . & S & V & $\mathbf{F}$ & . & A & & W & & L \\
\hline
\end{tabular}

Figure-2: Polymorphic amino acid sites of Catfish from site 233 to 378 . Identification with the first sequences is denoted by a dot.

Table-2: Amino acid variation of Indonesian catfish based on the Cytochrome B gene sequence.

\begin{tabular}{llcccccccccc}
\hline & & $\mathbf{1}$ & $\mathbf{2}$ & $\mathbf{3}$ & $\mathbf{4}$ & $\mathbf{5}$ & $\mathbf{6}$ & $\mathbf{7}$ & $\mathbf{8}$ & $\mathbf{9}$ & $\mathbf{1 0}$ \\
\hline 1 & $\mathrm{BB} 1,2,3$ & & & & & & & & & & \\
2 & $\mathrm{PM1} 1,2,3$ & 0 & & & & & & & & & \\
3 & $\mathrm{MP1} 1,2,3$ & 0 & 0 & & & & & & & & \\
4 & KR1 & 2 & 2 & 2 & & & & & & & \\
5 & KR2,3 & 0 & 0 & 0 & 2 & & & & & & \\
6 & KS1,2 & 2 & 2 & 2 & 0 & 2 & & & & & \\
7 & MS1,2,3 & 1 & 1 & 1 & 3 & 1 & 3 & & & & \\
8 & BF1,2,3,4 & 38 & 38 & 38 & 39 & 38 & 39 & 39 & & & \\
9 & EM1,2 & 31 & 31 & 31 & 32 & 31 & 32 & 30 & 49 & & \\
10 & BSBJ1,2,3 & 26 & 26 & 26 & 27 & 26 & 27 & 27 & 35 & 46 & \\
\hline
\end{tabular}

could be found in the rivers of Java, Sumatra, Kalimantan, Sulawesi, and Papua Island, may not possibly be determined based solely on the morphological characteristics. The morphological features are frequently utilized for the identification of other fish species. However, the similarity of morphological features from one catfish species to another can confound the identification of the catfish species [21]. The intention of this research was to determine the molecular characterization and phylogenetic relationship of the indigenous catfish from different parts of Indonesia known as Baung catfish by local people using Cyt B sequence.

In this present research, catfish samples Elo (Magelang, Central Java) and Bengawan Solo (Bojonegoro, East Java) from Java Island had some different amino acids compared to catfish samples from Kalimantan (BB; KS; MS) and Sumatra (KR; MP). These amino acid variations based on Cyt B amino acid sequences supported the confirmation that samples EM and BSBJ were different species than H. nemurus based on COX-III sequences [4]. Contrarywise, catfish sample Progo (Magelang, Central Java) which was originally from the different river, yet in the same province and same Java Island with catfish sample from Elo, had the identical amino acids with sample from Barito (Banjarmasin, South Kalimantan), as well as the sample from Musi (Palembang, South Sumatra), and two samples from Kampar (Riau, Sumatera). This investigation indicated that $H$. nemurus exists in Java, Kalimantan, and Sumatera Island. Comparing the catfish samples from Kalimantan (Barito, Mahakam, and Kapuas) and West Papua (Bomberay), there were 38-39 different amino acids between them. The most significant deviation on the amino acids was between catfish samples from Elo (Magelang, Central Java) and catfish samples from Bomberay (Fakfak, West Papua), which had 49 different amino acids. This concluded that the catfish samples from Bomberay were not closely related to other samples from Java, Sumatra, and Kalimantan. In other words, the catfish samples from Papua differed from catfish species from different regions in Indonesia based on the Cyt B amino acid sequence. The analysis of the mitochondrial Cyt B sequence confirmed the similarity of the morphological features of catfish in Indonesia. Therefore, species confirmation using the genetic analysis is truly useful to clarify the taxonomy diversification and evolutionary relationships within this plenteous group of fishes [22,23].

\section{Phylogenetic and phylogeographic of Indonesian catfish based on Cyt B sequence}

$H$. nemurus, initially being from Southeast Asia, had been reported in preceding studies to have an extensive genetic subdivision of the cluster based on the molecular phylogenetics and phylogeography [3,24-27]. To determine the phylogenetic relationship among the catfish from different parts of Indonesia, as well as comparing them with some other catfish species, this present study utilized the genetic sequence records of some species from the Siluriformes order. Constructed by the Cyt B nucleotides sequence, the catfish sample KR and MP (Sumatra); MS and BB (Kalimantan); and PM (Java) were in the same clade with $H$. nemurus and $H$. wyckioides, which was supported by bootstrap 63\% NJ. Other catfish samples from Kalimantan (KS) and one sample of KR (KR1) from Sumatra had genetic similarities with $S$. seenghala and H. spilopterus (bootstrap $100 \%$ NJ). In addition, other catfish samples from Java (BSBJ) were clustered with P. pleurotaenia (bootstrap 98\% NJ), while samples EM were together with M. cavasius (bootstrap 45\% NJ). Finally, catfish 


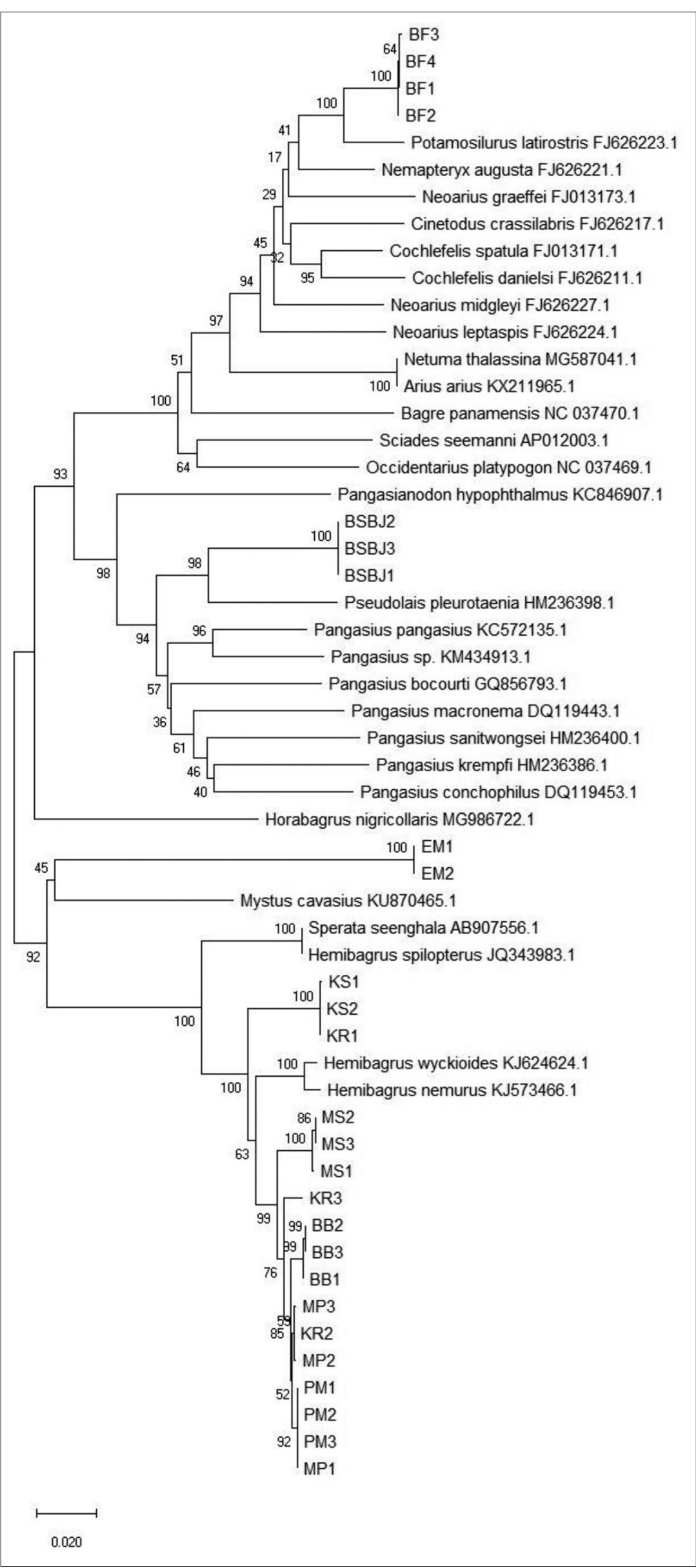

Figure-3: Phylogram of Indonesian catfish based on the cytochrome B nucleotides sequence. 


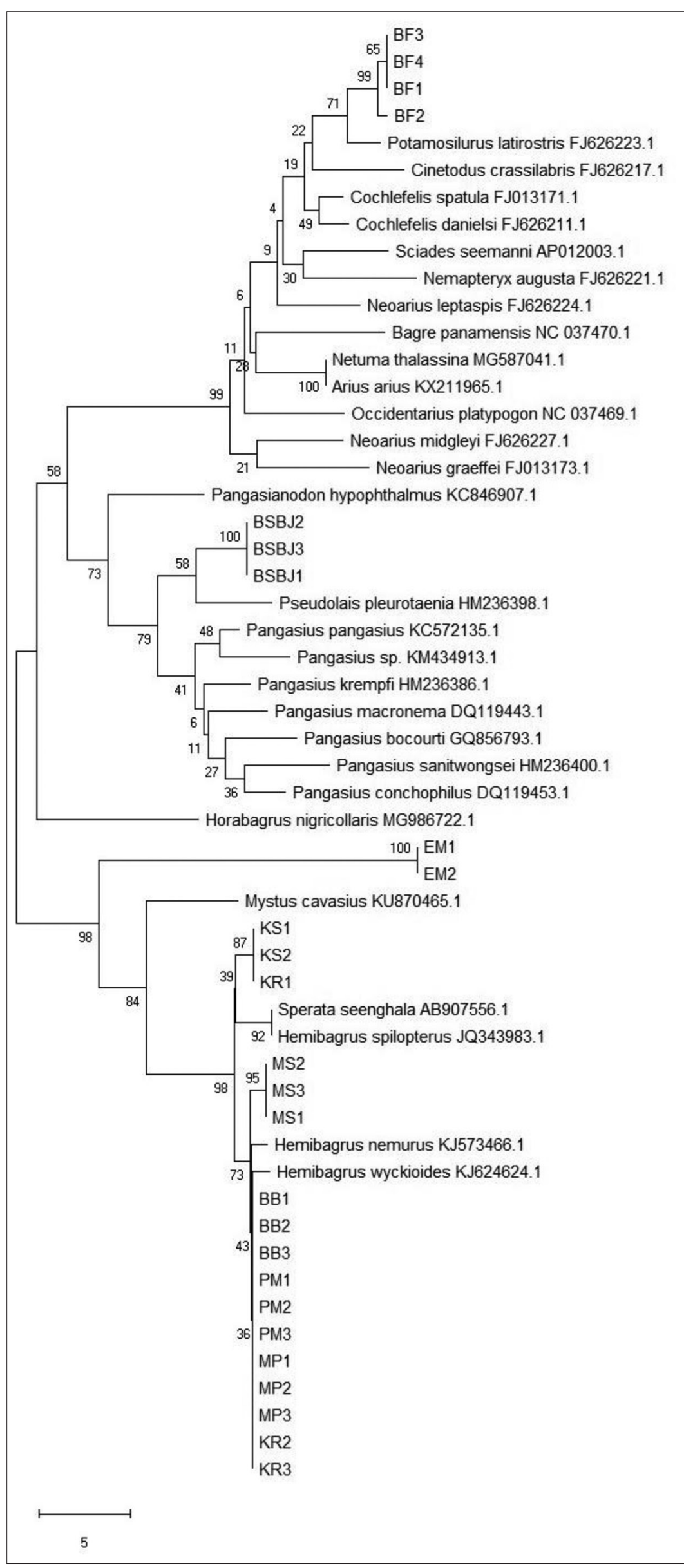

Figure-4: Phylogram of Indonesian catfish based on the cytochrome B amino acid sequence. 
samples from West Papua formed the same clade with P. latirostris, supported by bootstrap $100 \%$ NJ.

The phylogenetic tree of Indonesian catfish based on the Cyt B amino acid sequence was identical with the phylogenetic tree based on Cyt B nucleotides, where there were five different clades formed. However, the bootstrap supported that the monophyletic groups were different: Catfish sample KR and MP (Sumatra); MS and BB (Kalimantan); and PM (Java) were together with $H$. nemurus and $H$. wyckioides supported by bootstrap $73 \%$ NJ. Catfish samples from Kalimantan (KS) and one sample of KR (KR1) from Sumatra were in the same group with $S$. seenghala and H. spilopterus favored by bootstrap 39\% NJ. Other catfish samples from Java (BSBJ) were clustered with P. pleurotaenia (bootstrap 58\% NJ), while samples EM were together with $M$. cavasius (bootstrap 98\% NJ). Finally, catfish samples from West Papua formed the same clade with $P$. latirostris, supported by bootstrap $71 \%$ NJ.

These results uncovered that all samples from different parts of Indonesia were divided into five different species of catfish based on the mtDNA Cyt B sequence. The five different species belonged to three different families: Bagridae, Pangasiidae, and Ariidae. Our samples generally consisted of Bagridae family that was distributed from Sumatera, Central Java, and Kalimantan. Interestingly, we found that samples from Bojonegoro, East Java belonged to Pangasiidae. The phylogenetically distinct Papuan samples had their places in the Ariidae, which mostly contained the coastal to estuaries catfish [28], while our samples were collected from the river sources.

These results of our analyses were identical to a previous study using the COX-III sequences [4]. Besides, these results also supplemented the research done by Dodson and Lecomte [27], which determined that Indonesian catfish were comprised of three species based on the mtDNA Cyt B: Hemibagrus planiceps from Java; Hemibagrus bongan from Kalimantan, and Hemibagrus velox from Sumatra. In fact, there were additional catfish species from different parts of Indonesia discovered in this study, despite the similarity of their morphological features. The geographical adjustments which have occurred in Indonesian lands throughout the geological history have influenced the speciation and the alterations of the mtDNA of Indonesian catfish species, forming their recent common lineages. Therefore, to distinguish the group of Indonesian catfish, the phylogenetic analysis based on the DNA sequence is definitely needed for the species' successful conservation.

\section{Conclusion}

Indonesian catfish were divided into five clades or monophyletic groups based on Cyt B gene. Catfish sample KR and MP (Sumatra); MS and BB (Kalimantan); and PM (Java) were clustered with $H$. nemurus and H. wyckioides (Bagridae family).
Samples from Kalimantan (KS) and one sample of KR (KR1) from Sumatra were clustered with $S$. seenghala and H. spilopterus (Bagridae family). Other catfish samples from Java (BSBJ) were clustered with P. pleurotaenia (Pangasiidae family), while samples EM were together with M. cavasius (Bagridae family). Finally, catfish samples from West Papua were clustered with P. latirostris (Ariidae family).

\section{Authors' Contributions}

RW designed and collected samples for this study. DVM, HAN, ZPA, and YDRBRS carried out the research in the laboratory. RW, DVM, and HAN analyzed, wrote, and revised the manuscript. All authors have read and approved the final manuscript.

\section{Acknowledgments}

This study was financially supported by Universitas Gadjah Mada, Indonesia (Grant number: 3097/UN1/DITLIT/DIT-LIT/LT/2019). The authors would like to thank Erik Hookom, as well as all the staff and students at the Department of Biochemistry and Molecular Biology, Faculty of Veterinary Medicine, Universitas Gadjah Mada.

\section{Competing Interests}

The authors declare that they have no competing interests.

\section{Publisher's Note}

Veterinary World remains neutral with regard to jurisdictional claims in published institutional affiliation.

\section{References}

1. Kottelat, M., Whiten, A.J., Kartikasari, S.N. and Wirjoatmodjo, S. (1993) Freshwater Fishes of Western Indonesia and Sulawesi. Periplus Editions (HK) Ltd., Collaboration with the Environmental Management Development in Indonesia (EMDI) Project Ministry of State for Population and Environment, Indonesia.

2. Mesomya, W., Cuptapun, Y., Jittanoonta, P., Hengsawadi, D., Boonsivut, S., Huttayanon, P. and Sriwatana, W. (2002) Nutritional evaluations of green catfish, Mystus nemurus. J. Nat. Sci., 36(1): 69-74.

3. Syaifudin, M., Jubaedah, D., Muslim, M. and Daryani, A. (2018) DNA authentication of Asian redtail catfish Hemibagrus nemurus from Musi and Penukal river, South Sumatra Indonesia. Genet. Aquat. Organ., 1(1): 43-48.

4. Widayanti, R., Haryanto, A., Artama, W.T. and Pakpahan, S. (2019) Genetic variation and phylogenetic analysis of Indonesian indigenous catfish based on mitochondrial cytochrome oxidase subunit III gene. Vet. World, 12(6): 896-900.

5. Peter, K.L. and Ng, H.H. (1995) Hemibagrus gracilis, a new species of large riverine catfish (Teleostei: Bagridae) from Peninsular Malaysia. Raffles. Bull. Zool., 43(1): 133-142.

6. Parson, W., Pegoraro, K., Niederstatter, H., Foger, M. and Steinlechner, M. (2000) Species identification by means of the cytochrome B gene. Int. J. Legal Med., 114(1-2): 23-28.

7. Lerner, H.L.R. and Mindell, D.P. (2005) Phylogeny of eagles, old world vultures, and other Accipitridae based on nuclear and mitochondrial DNA. Mol. Phylogenet. Evol., 37(2): 327-346.

8. Shephard, J.M., Catterall, C.P. and Hughes, J.M. (2005) Long-term variation in the distribution of the white-bellied 
sea-eagle (Haliaeetus leucogaster) across Australia. Austral Ecol., 30(2): 131-145.

9. Budiarsa, I.M. (2013) Gen Cytochrome B Sebagai Marker Filogenetik, Untuk Analisis Hubungan Kekerabatan Burung Maleo (Macrocephalon maleo) di Habitat Alami. Seminar. Nasional ke-22, Perhimpunan Biologi Indonesia.

10. Pakpahan, S., Artama, W.T., Widayanti, R. and Suparta, I.G. (2016) Genetic characteristics and relationship in different goat populations of Indonesia based on cytochrome B gene sequences. Asian J. Anim. Sci., 10(1): 29-38.

11. Maulid, D.Y., Nurilmala, M., Nurjanah, N. and Maddupa, H. (2016) Karakterisasi molekuler cytochrome B untuk DNA barcoding ikan tenggiri. JPHPI, 19(1): 9-16.

12. Kunda, R.M., Handayani, N.S.N., Wijayanto, H. and Widayanti, R. (2016) Study of genetic marker of cuscuses (Marsupialia: Phalangeridae) from Maluku and Papua based on cytochrome B gene sequences. Pak. J. Biol. Sci., 19(3): 122-135.

13. Farias, I.P., Orti, G., Sampaio, I., Schneider, H. and Mayer, A. (2001) The cytochrome B gene as a phylogenetic marker: The limits of resolution for analyzing relationship among Cichlid fishes. J. Mol. Evol., 53(2): 89-103.

14. Kocher, T.D., Thomas, W.K., Meyer, K., Edwards, S.V., Paabo, S., Villablanca, F.X. and Wilson, A.C. (1989) Dynamics of mitochondrial DNA evolution in animals: Amplification and sequencing with conserved primers. Proc. Natl. Acad. Sci. USA, 86(16): 6196-6200.

15. Irwin, D.M., Kocher, T.D. and Wilso, A.C. (1991) Evolution of the cytochrome b gene of mammals. J. Mol. Evol., 32(2): 128-144.

16. Hebert, P.D.N., Ratnasingham, S. and de Waard, J.R. (2003) Barcoding animal life: Cytochrome c oxidase subunit 1 divergence among closely related species. Proc. Biol. Sci., 270(1): 96-99.

17. Catresana, J. (2001) Cytochrome B phylogeny and the taxonomy of great apes and mammals. Mol. Biol. Evol., 18(4): 465-471.

18. Kumar, S., Stecher, G., Li, M., Knyaz, C. and Tamura, K. (2018) MEGA X: Molecular evolutionary genetics analysis across computing platforms. Mol. Biol. Evol., 35(6): 1547-1549.

19. Kumar, S. (1996) Patterns of nucleotide substitution in mitochondrial protein-coding genes of vertebrates. Genetics, 143(1): 537-548.

20. Ferraris, C.J. (2007) Checklist of catfishes, recent and fossil (Osteichthyes: Siluriformes), and catalog of Siluriform primary types. Zootaxa, 1418(1): 1-628.

21. Ng, H.H. and Kottelat, M. (2013) Revision of the Asian catfish genus Hemibagrus Bleeker, 1862 (Teleostei: Siluriformes: Bagridae). Raffles. Bull. Zool., 61(1): 205-291.

22. Buj, I., Šanda, R., Marčić, Z., Ćaleta, M. and Mrakovčić, M. (2014) Combining morphology and genetics in resolving taxonomy-a systematic revision of spined loaches (genus Cobitis; Cypriniformes, Actinopterygii) in the Adriatic watershed. PLoS One, 9(6): e99833.

23. Ikabanga, D.U., Stevart, T., Koffi, K.G., Monthe, F.K., Doubindou, E.C.N., Dauby, G. and Hardy, O.J. (2017) Combining morphology and population genetic analysis uncover species delimitation in the widespread African tree genus Santiria (Burseraceae). Phytotaxa, 321(2): 166-180.

24. Hee, H.H. and Rachmatika, I. (1999) The catfishes (Teleostei: Siluriformes) of Bentuang Karimun national park, West Kalimantan, Indonesia. Raffles Bull. Zool., 47(1): 167-183.

25. Dodson, J.J., Colombani, F. and Ng, P.K.L. (1995) Phylogeographic structure in mitochondrial DNA of a South-East Asian freshwater fish, Hemibagrus nemurus (Siluroidei; Bagridae) and Pleistocene sea-level changes on the Sunda shelf. Mol. Ecol., 4(3): 331-346.

26. Dodson, J.J. (1999) Morphological and genetic description of a new species of catfish, Hemibagrus chrysops, from Sarawak, East Malaysia, with an assessment of phylogenetic relationships (Teleostei: Bagridae). Raffles. Bull. Zool., 47(1): 45-58.

27. Dodson, J.J. and Lecomte, F. (2015) A DNA barcode-based evaluation of the Southeast Asian catfish genus Hemibagrus Bleeker, 1862 (Teleostei: Siluriformes; Bagridae). Adv. Evol. Biol., 2015(1): 21.

28. Denadai, M.R., Bessa, E., Santos, F.B., Fernandez, W.S., Santos, F.M.C., Feijo, M.M., Arcuri, A.C.D. and Turra, A. (2012) Life history of three catfish species (Siluriformes: Ariidae) from Southeastern Brazil. Biota Neotrop., 12(4): 74-83.

$* * * * * * * *$ 